\title{
Physical Education Teachers' Understanding of the 2013 Curriculum
}

\author{
Bayu Hardiyono ${ }^{1, *}$, Riyan Pratama ${ }^{1}$, Arif Hidayat ${ }^{1}$, Hartati $^{2}$ \\ ${ }^{1}$ Faculty of Education and Teacher Training, Universitas Bina Darma, Palembang, 30264, Indonesia \\ ${ }^{2}$ Faculty of Education and Teacher Training, Universitas Sriwijaya, Indralaya, 30662, Indonesia
}

Received September 22, 2020; Revised November 19, 2020; Accepted November 27, 2020

\begin{abstract}
Cite This Paper in the following Citation Styles
(a): [1] Bayu Hardiyono, Riyan Pratama, Arif Hidayat, Hartati, "Physical Education Teachers' Understanding of the 2013 Curriculum," International Journal of Human Movement and Sports Sciences, Vol. 9, No. 5, pp. 841 - 846, 2021. DOI: $10.13189 /$ saj.2021.090502.
\end{abstract}

(b): Bayu Hardiyono, Riyan Pratama, Arif Hidayat, Hartati (2021). Physical Education Teachers' Understanding of the 2013 Curriculum. International Journal of Human Movement and Sports Sciences, 9(5), 841 - 846. DOI: 10.13189/saj.2021.090502.

Copyright $\bigcirc 2021$ by authors, all rights reserved. Authors agree that this article remains permanently open access under the terms of the Creative Commons Attribution License 4.0 International License

\begin{abstract}
This study aims to determine the level of understanding of the teachers in physical education, sports, and health in Muara Padang sub-District about 2013 Curriculum Learning. The research method used in this research is quantitative descriptive. The sample in this study is elementary school teachers in Line 20, Muara Padang sub-district, Banyuasin district with a total of 34 teachers. This study uses 3 indicators, namely understanding the PJOK learning syllabus in the 2013 curriculum, understanding the principles of preparing RPP in learning PJOK in the 2013 curriculum, and understanding the methods in learning PJOK in the 2013 curriculum. The PJOK learning syllabus in the 2013 curriculum got an average score of 54.8 with a percentage of $35.3 \%$ and was included in the high category, then for the level of understanding of PJOK teachers in understanding the principles of preparing RPP in learning PJOK in the 2013 curriculum, they received an average value of 43.16 with a percentage of $29.43 \%$ and included in the high category, then the level of understanding of PJOK teachers in understanding the methods of learning PJOK in the 2013 curriculum got an average score of 43.04 with a percentage of $38.23 \%$ and entered in the high category.
\end{abstract}

Keywords Curriculum 2013, Physical Education Teachers

\section{Introduction}

Education is the main thing that can sustain the progress of a nation. Without education, a country will be far behind other countries. Traditionally, schools around the world have emphasized academic achievement, driven by the imperative to prepare children for the job market [1]. When measured from the quality and existing education system, educational institutions carry the mandate to prepare their students to be able to survive and have character [2]. Based on a survey conducted by Political and Economic Risk Consultants (PERC) in 2012 [5], the quality of education in Indonesia ranks 12th out of 12 countries in Asia, the results of this survey are quite alarming. Meanwhile, the results of a survey conducted by The World Economic Forum Sweden (2000) show that Indonesia has very low competitiveness, only ranking 37 th out of 57 countries included in this survey [3].

We can observe various clear pieces of evidence of the decline in education in Indonesia every day. Starting from violence in the attitudes of students, acts of sexual harassment, to acts of violence perpetrated by students against teachers or educators, so that various negative things that have emerged have aggravated the education system in Indonesia. [4]. The current conditions are very irrelevant to the objectives of Law number 20 of 2003 concerning the National Education System. Where in article 3 states that the creation of the National Education System is to form a dignified character and civilization of 
the nation to educate the nation's life. One of the ways is by developing the potential of students to become human beings who believe and obey God Almighty, have a noble character, are healthy, knowledgeable, capable, creative, independent, and become democratic and responsible citizens. This education system is also expected to be able to prepare the Indonesian nation to face challenges in the future, as stated by Huntington [5].

To create the expected conditions, it is necessary to have the suitability of each supporting component in achieving the goals of education itself. One of them is the curriculum. The curriculum is used to describe a set plan, a complete set of experiences, or content that is measured from an experience; as a single class session, a group of classes, or a defined learning period [6]. Besides, the curriculum must be able to make the current generation think creatively and innovatively, have character, love the country, and are proud to be the Indonesian nation. The development of an effective curriculum must meet the current and needs of the culture, society, and expectations of the population it serves [7]. The education system in Indonesia has undergone several changes in the curriculum, it started from the pre-independence period curriculum to the latest 2013 curriculum. Changes in this curriculum affect the standards and components of education. The curriculum must always be updated in line with changes to remain relevant to changes in society [8]. Particularly in the 2013 curriculum, authentic assessment becomes a serious emphasis when the teacher assesses the learning outcomes of students. For example, by adding competencies outside the learning material

Physical competence is one of the elements of learning [9]. In the subjects of Physical Education, Sports, and Health (PJOK) which are included in the 2013 curriculum, the application pattern can be integrated with separate basic competencies. For example, in the curriculum structure for PJOK subjects, which are allocated 3 hours of lessons each week, it can be added according to the development of competency in movement and a healthy lifestyle, which gives color to the nation's character education through local wisdom. Like getting to know traditional games and sports that are rooted in the culture of the Indonesian people so that they contribute to character building. Because physical education is a subject that can improve the development of life skills and the psychological well-being of students [10].

The understanding of the 2013 curriculum differs in each region. In an article written by Moch. [1] explained that the implementation of the 2013 curriculum for junior high school level PJOK subjects at One Roof Schools on Gili Ketapang Island and target schools in the Probolinggo Regency area has not been fully implemented. The results of his research showed that the percentage of understanding for One Roof Junior Secondary School in Gili Ketapang was $72.38 \%$, while the target One Roof system School in Probolinggo Regency was $74.39 \%$ and both were in the sufficient category. Meanwhile, referring to the article written by Alawiyah [11], junior high school in Lamongan Regency is very familiar with the content of the 2013 curriculum. This can be seen from the results of filling out a questionnaire that was distributed to junior high school teachers in the Lamongan district, including in the very understanding category.

The 2013 curriculum is also implemented in Muara Padang Sub-District, Banyuasin Regency, South Sumatra, Indonesia. Muara Padang sub-district consists of fifteen villages, namely Karang Anyar, Tanjung Baru, Muara Padang, Margomulyo, Purwodadi, Sumber Makmur, Sidomulyo, Air Gading, Tirtoraharjo, Tirtajaya, Sidorejo, Margo Sugihan, Sidomulyo, Daya Makmur, and Daya Utama. Based on the observations of researchers in Muara Padang Subdistrict to be precise on Line 20, there are a number of State Elementary Schools whose teachers are required to understand the 2013 Curriculum. The sub-district has a different understanding of the 2013 Curriculum.

The contributing factor is that not all teachers follow the training conducted by the Education Office after, besides that, the lack of adequate facilities and infrastructure, so that they cannot support the learning process optimally, is also the cause of the lack of understanding of these teachers. So it can be concluded that the quality of education in Line 20 is quite behind when compared to education in other areas in Banyuasin and even Palembang, South Sumatra.

From this study, researchers sought to find out in detail the extent to which the level of understanding of the teachers in the PJOK subjects understood the PJOK learning syllabus in the 2013 curriculum, the principles of preparing lesson plans and teaching methods in learning PJOK in the 2013 curriculum.

\section{Material Methods}

This research is a non-experimental study with a descriptive-quantitative approach. According to [12], this type of non-experimental research is where the author does not have the opportunity to provide treatment or manipulate variables that may play a role in the appearance of a symptom. The research design carried out is to take a sample from one population and use a questionnaire as a research instrument based on deductive logic. Whereas explained again by [12], deductive logic is to use theory as the basis of research and then end with an analysis of measurement data.

The population in this study were 34 primary school Physical education (PJOK) teachers, namely: SD Negeri 1 Muara Padang, SD Negeri 2 Muara Padang, SD Negeri 3 Muara Padang, SD Negeri 4 Muara Padang, SD Negeri 5 Muara Padang, SD Negeri 7 Muara Padang, SD. Negeri 10 Muara, Padang, SD Negeri 11 Muara Padang, SD 
Negeri 12 Muara Padang, SD Negeri 13 Muara Padang, SD Negeri 14 Muara Padang, SD Negeri 15 Muara Padang, SD Negeri 16 Muara Padang, SD Negeri 17 Muara Padang, SD Negeri 19 Muara Padang, SD Negeri 20 Muara Padang, SD Negeri 21 Muara Padang. Sampling in this study used total sampling where the sample used was all PJOK teachers in the area of Jalur 20, Muara Padang District, South Sumatra, totaling 34 sample.

The instrument used in this study was in the form of a questionnaire. The questionnaire contained positive and negative statements aimed at comparing the consistency of answers. As a data collection tool, this questionnaire was presented in a closed-form so that respondents simply chose the answers provided. The score used in this study uses a Likert scale which has five alternative answers, namely: strongly agree / often, agree / often, doubt / sometimes, disagree / rarely, and strongly disagree / never. Alternative answers are hesitant to remove so that the answer is more optimal. So that there are four alternative answers provided. The scoring of each answer is as follows:

Table 1. Likert Scale Table

\begin{tabular}{|c|c|c|c|}
\hline Answers & Code & Positive Score & Score \\
\hline Strongly Agree & SS & 4 & 1 \\
\hline Agree & S & 3 & 2 \\
\hline Disagree & TS & 2 & 3 \\
\hline Strongly Disagree & STS & 1 & 4 \\
\hline
\end{tabular}

Source: [13]

To find out in more depth how teachers understand the 2013 curriculum, the following is a grid of research instruments with criteria based on Permendikbud Number 20 of 2016 concerning Competency Standards for Primary and Secondary Education Graduates [14], Permendikbud Number 21 of 2016 concerning Content Standards for Primary and Secondary Education [15], Permendikbud Number 22 of 2016 concerning Basic and Secondary Education Process Standards [16], Permendikbud Number 23 of 2016 concerning Educational Assessment Standards [17], and Permendikbud Number 24 of 2016 concerning Core Competencies and Basic Competencies of Lessons in the 2013 Curriculum in Primary and Secondary Education [18].

The initial process of data analysis is to describe the data taken from filling out the questionnaire by the PJOK subject teachers. The researcher then organized the data and described it into units, then described the results of the collection of instruments that were the subject of the research again. The data analysis technique used was descriptive-quantitative, with the following formula:

$$
\text { percentage }=\frac{\text { total score }}{\text { total highest scores }} \times 100 \%
$$

For the assessment scale, the researcher uses a Likert scale, which is where the scaling method that uses the response distribution is very understanding-do not understand as a basis for determining value, [2]. The distribution of answers is on a psychological continuum ranging from $1-4$.

$1=$ Don't understand

$2=$ Don't really understand

$3=$ Understand

$4=$ Very Understand

\section{Result and Discussion}

\section{Result}

The data of this study consisted of data on the level of understanding of PJOK teachers in elementary schools, the level of understanding of PJOK subject teachers, namely understanding the learning syllabus of PJOK in the 2013 curriculum, understanding the principles of preparing RPP in learning PJOK in the 2013 curriculum, and understanding the methods of learning PJOK in the 2013 curriculum. The elementary school in Jalur 20, Muara Padang sub-district, Banyuasin district is described as follows:

\section{a) Understanding the Learning Syllabus of PJOK in the 2013 Curriculum for Elementary School Levels}

The results obtained from 34 teachers where the lowest score (minimum) was 52, the highest score (maximum) was 56, and the average score (mean) was 54.8. The results that have been obtained are then converted into four categories, as follows:

Table 2. Percentage of PJOK Learning Syllabus Understanding in the 2013 Curriculum at the Elementary School Level

\begin{tabular}{|c|c|c|c|c|}
\hline No & Range & Category & Frequency & Percentage \\
\hline 1 & $55<\mathrm{X} \leq 56$ & Very High & 6 & $17.7 \%$ \\
\hline 2 & $54<\mathrm{X} \leq 55$ & High & 12 & $35.3 \%$ \\
\hline 3 & $53<\mathrm{X} \leq 54$ & Low & 11 & $32.3 \%$ \\
\hline 4 & $52<\mathrm{X} \leq 53$ & Very Low & 5 & $14.7 \%$ \\
\hline \multicolumn{2}{|c|}{ Total } & & 34 & $100 \%$ \\
\hline
\end{tabular}

Based on the table, it shows that, in the "very high" category of $17.7 \%$ (6 teachers), "high" of $35.3 \%$ (12 teachers), "low" of 32.3 (11 teachers), and "very low" of $14.7 \%$ ( 5 teachers). Based on these results in general it is in the "High" category. 


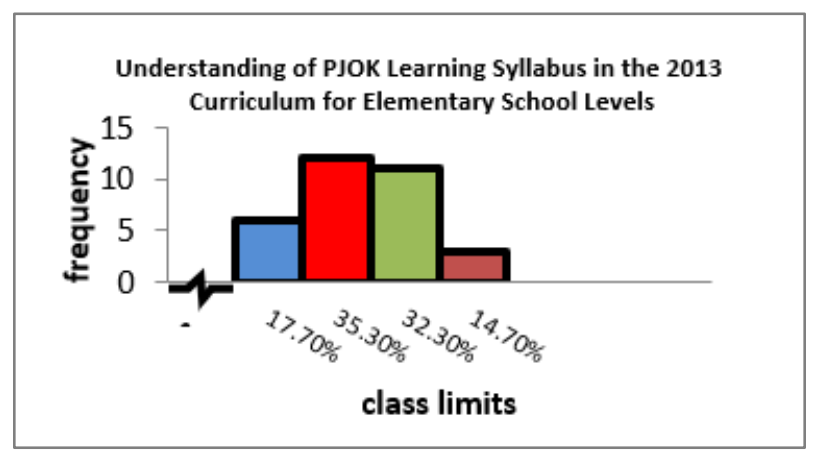

Figure 1. The histogram of understanding the PJOK learning syllabus in the 2013 curriculum at the elementary school level

\section{b) Understanding the Principles of RPP Preparation in PJOK Learning in the 2013 Curriculum for Elementary School Levels}

The results obtained from 34 teachers where the lowest score (minimum) was 40 , the highest score (maximum) was 44 , and the average score (mean) was 43,16 . The results that have been obtained are then converted into four categories, as follows:

Table 3. Percentage of understanding of the Principles of Preparation of RPP in Learning PJOK at the 2013 Curriculum at the Elementary School Level

\begin{tabular}{|c|c|c|c|c|}
\hline No & Range & Category & Frequency & Percentage \\
\hline 1 & $43<\mathrm{X} \leq 44$ & Very High & 9 & $26.47 \%$ \\
\hline 2 & $42<\mathrm{X} \leq 43$ & High & 10 & $29.43 \%$ \\
\hline 3 & $41<\mathrm{X} \leq 42$ & Low & 7 & $20.8 \%$ \\
\hline 4 & $40<\mathrm{X} \leq 41$ & Very Low & 8 & $23.3 \%$ \\
\hline \multicolumn{2}{|c}{ Total } & & 34 & $100 \%$ \\
\hline
\end{tabular}

The table shows that, in the "very high" category of $26.47 \%$ (9 teachers), "high" of $20.56 \%$ (7 teachers), "low" of $38.23 \%$ (13 teachers), and "very low" of $14.74 \%$ (5 teachers). Based on these results in general it is in the "High" category.

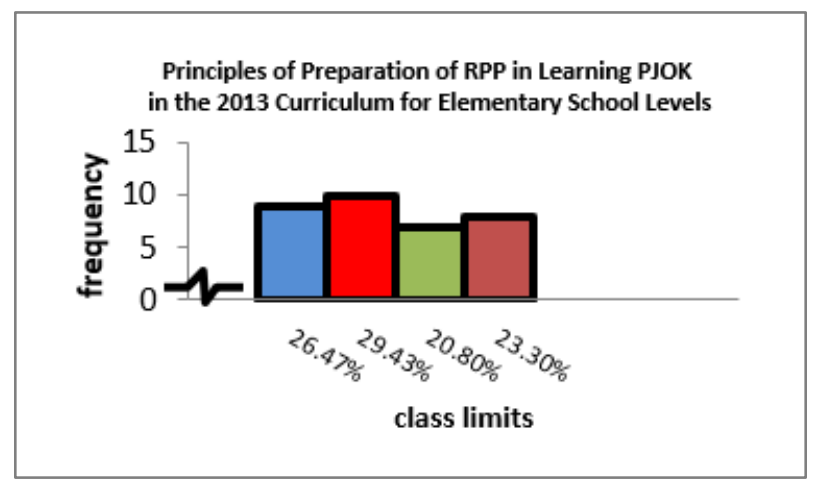

Figure 2. The histogram of the Principles of RPP Preparation in the 2013 curriculum at the elementary school level

c) Understand Methods in Learning PJOK in the 2013 Curriculum for Elementary School Levels

The results obtained from 34 teachers where the lowest score (minimum) was 40 , the highest score (maximum) was 44 , and the average score (mean) was 43,04 . The results that have been obtained are then converted into four categories, as follows

Table 4. Percentage of Understanding Methods in Learning PJOK in the 2013 Curriculum at Elementary School Level

\begin{tabular}{|c|c|c|c|c|}
\hline No & Range & Category & Frequency & Percentage \\
\hline 1 & $43<\mathrm{X} \leq 44$ & $\begin{array}{c}\text { Very } \\
\text { High }\end{array}$ & 8 & $23.56 \%$ \\
\hline 2 & $42<\mathrm{X} \leq 43$ & High & 13 & $38.23 \%$ \\
\hline 3 & $41<\mathrm{X} \leq 42$ & Low & 11 & $32.3 \%$ \\
\hline 4 & $40<\mathrm{X} \leq 41$ & $\begin{array}{c}\text { Very } \\
\text { Low }\end{array}$ & 2 & $5.88 \%$ \\
\hline \multicolumn{2}{|c|}{ Total } & & 34 & $100 \%$ \\
\hline
\end{tabular}

The table shows that the "very high" category is $23.56 \%$ (8 teachers), "high" is $38.23 \%$ (13 teachers), "low" is $32.3 \%$ (11 teachers), and "very low" is $5.88 \%$ ( 2 teachers). Based on these results in general it is in the "High" category.

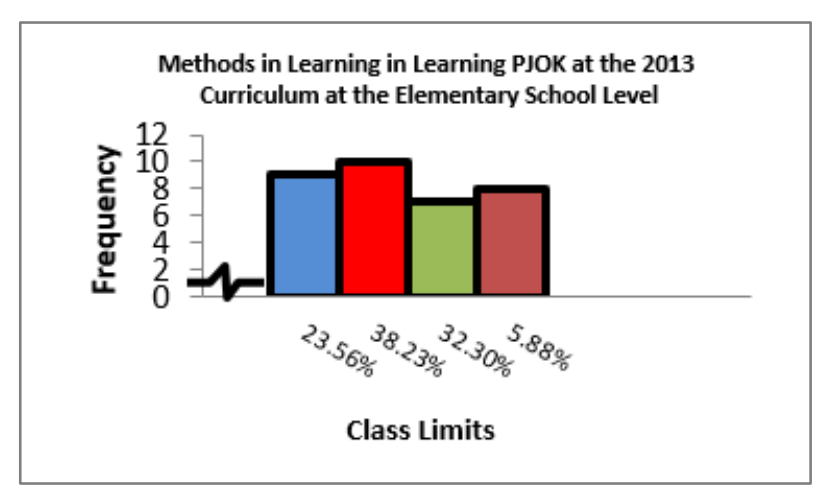

Figure 3. The histogram of understanding the method in learning PJOK in the 2013 curriculum at the elementary school level

\section{Discussion}

The educational curriculum provides teachers with opportunities to learn new skills and practices [19]. Curriculum materials serve as the primary conceptual tool for teachers, as well as with a better understanding of how science teachers use these tools can help improve curriculum design and theory related to teacher learning and decision making [20] This study aims to determine how high the level of understanding of PJOK teachers in Muara Padang District about learning curriculum 2013. The data collection instrument is a questionnaire. The data analysis technique used is descriptive analysis by using a percentage calculation.

Based on the results of the research, the level of understanding of PJOK teachers in elementary schools in Muara Padang Sub-District in understanding the learning syllabus of PJOK in the 2013 curriculum, got an average score of 54.8 with a percentage of $35.3 \%$ and was in the high category. The level of understanding of PJOK 
teachers in understanding the principles of preparing lesson plans in teaching PJOK in the 2013 curriculum received an average value of 43.16 with a percentage of $29.43 \%$ and was included in the high category. Furthermore, the level of understanding of PJOK teachers in understanding PJOK learning methods in the 2013 curriculum got an average score of 43.04 with a percentage of $38.23 \%$ and was included in the high category.

The implementation of the 2013 curriculum in Muara Padang Sub-District has been considered good because, from the results of observations made by researchers, it is known that PJOK Elementary School teachers in Muara Padang Sub-District started learning by designing a learning plan in the form of a syllabus and learning implementation plan which is a description of the core competencies and basic competencies that have been determined by the National Education Standards Agency.

The roles and responsibilities of the teacher in developing the syllabus are analyzing competency designs and competency indicators and standard materials, compiling lesson plans, developing learning strategies, and developing learning media and methods.

Based on the results of interviews and document studies, the curriculum document is in the form of a syllabus created by the teacher under the format and procedures for developing the syllabus. The syllabus format is still based on the education unit level curriculum, at least covering competency standards, basic competencies, indicators, standard materials, standards for teaching and learning activities, and assessment standards. The procedure in developing a syllabus in outline included filling in the identity column, reviewing and analyzing competency standards and basic competencies, identifying standard material, developing learning experiences, formulating indicators, determining the type of assessment, allocation, time and learning resources, while the syllabus model developed by the teacher in schools it can be modified, adapted to the characteristics of students, the situation and conditions of the school and area by still adhering to the standard of competence and basic competence. Based on data in the field, it is revealed that, in making a learning planning program or an elementary school platform, several things need to be considered by the teacher, namely learning objectives (competency standards and basic competencies), learning materials, media, and learning methods, student learning experiences and formulating indicators.

Teachers' understanding of the 2013 curriculum is also supported by school programs and government programs through the Subject Teacher Conference (MGMP) activities, especially teachers of Physical Education, Sports and Health (PJOK) in their respective schools, 2013 curriculum development workshops, and related activities. With this program, teachers can understand the structure and framework of the 2013 curriculum learning unit and its application in learning activities in the classroom. From the results of this study, it is in accordance with the research that curriculum 13 can be implemented and carried out by schools with the need to adjust the ability of sports infrastructure in schools. [21]

\section{Conclusions}

The implementation of the 2013 curriculum is the entire learning process, the formation of competence and character of the planned trainees. For this purpose, the core competence, basic competence, standard material, standard material, indicators of learning outcomes, and time must be determined according to the interests of learning so that students are expected to get optimal learning opportunities and experiences. In this case, learning is essentially a process of interaction between students and their environment, resulting in changes in behavior towards a better direction. In general, learning activities include starting or opening activities, these activities or the formation of competence and character, as well as final or closing activities.

The implementation of the 2013 curriculum in Line 20, Muara Padang District has been considered good. The Learning Plan, both the syllabus and the learning implementation plan developed by the teacher in Muara Padang District, refers to the content standard (competency and basic competency standards) and the graduate competency standards are in accordance with the steps and formats expected in the development of the syllabus and lesson plans. in the education unit level curriculum.

\section{Suggestion}

Schools must be able to facilitate the learning of Physical Education, Sports, and Health (PJOK) optimally so that the learning objectives are maximally achieved. The learning material presented to students must be an effort to achieve predetermined basic competencies. Also, the competence of PJOK teachers at the Elementary School level must be improved according to the 2013 Curriculum targets. This competency improvement can be done by increasing the intensity of sending teachers to attend seminars, workshops, training, and Subject Teacher Deliberation (MGMP) so that teachers' understanding of the concept of the 2013 Curriculum is clearer, so that teaching preparation, learning concepts and assessment development concepts are following the signs for implementing the 2013 Curriculum. 


\section{REFERENCES}

[1] M. A. Sultoni and A. Rachman, "Keterlaksanaan Kurikulum 2013 Mata Pelajaran Pjok Tingkat Smp Pada Sekolah Satu Atap Di Pulau Gili Ketapang Dan Wilayah Kabupaten Probolinggo," J. Pendidik. Olahraga dan Kesehat., vol. 3, no. 1, pp. 243-248, 2013.

[2] A. Farihatun Nisa, "IMPLEMENTASI KURIKULUM BERBASIS KEARIFAN LOKAL DI SD NEGERI JARAKAN PANGGUNGHARJO SEWON BANTUL," Inspirasi Manaj. Pendidik., 2017.

[3] Sujarwo, "Pendidikan di Indonesia memprihatinkan," J. Ilm. WUNY, vol. XV, no. 1, 2013, doi: https://doi.org/10.21831/j wuny.v15i1.3528.g3005.

[4] U. R. N. 20 T. Undang-undang RI No. 20, 2003, "Undang-Undang Republik Indonesia Nomor 20 Tahun 2003 Tentang Sistem Pendidikan Nasional Dengan Rahmat Tuhan Yang Maha Esa Presiden Republik Indonesia," Zitteliana, 2003

[5] M. Nuh, Menyemai kreator peradaban: renungan tentang pendidikan, agama, dan budaya, 1st ed. Jakarta: Zaman, 2013.

[6] J. Jung, J. Ressler, and A. Linder, "Exploring the Hidden Curriculum in Physical Education," Adv. Phys. Educ., vol. 8, no. 2, pp. 253-262, 2018, doi: 10.4236/ape.2018.82023.

[7] M. A. Alsubaie, "Teacher Involvement in Curriculum Development," J. Educ. Pract., vol. 7, no. 9, pp. 106-107, 2016.

[8] C. R. Prihantoro, "The perspective of curriculum in Indonesia on environmental education," Int. J. Res. Stud. Educ., vol. 4, no. 1, pp. 77-83, 2015, doi: 10.5861/ijrse.2014.915

[9] A. Sprake and S. Walker, "Blurred lines': The duty of physical education to establish a unified rationale," Eur. Phys. Educ. Rev., 2015, doi: 10.1177/1356336X15577221.

[10] L. D. Cronin, J. Allen, C. Mulvenna, and P. Russell, "An investigation of the relationships between the teaching climate, students' perceived life skills development and well-being within physical education," Phys. Educ. Sport
Pedagog., 2018, doi: 10.1080/17408989.2017.1371684.

[11] F. Alawiyah, "Peran Guru Dalam Kurikulum 2013 The Role of Teacher in Curricullum 2013," Aspirasi, 2013.

[12] A. Maksum, Metode Penelitian Dalam Olahraga. Surabaya: Surabaya: Unesa University Press, 2012.

[13] Sugiyono, "Metode Penelitian Pendidikan pendekatan Kuantitatif, Kualitatif dan R\&D.," in METODE PENELITIAN ILMIAH, 2014

[14] Kemendikbud, "Permendikbud No 020 tahun 2016 Tentang Standar Kompetensi Lulusan Pendidikan Dasar Dan Menengah,” Jakarta, Indonesia, 2016.

[15] Kemendikbud, "Permendikbud No 021 tahun 2016 Tentang Standar Isi Pendidikan Dasar dan Menengah,” Jakarta, 2016.

[16] Kemendikbud, "Peraturan Menteri Pendidikan Dan Kebudayaan Nomor 22 Tahun 2016 Tentang Standar Proses Pendidikan Dasar Dan Menengah,” Jakarta, 2016.

[17] Kemendikbud, "Peraturan Menteri Pendidikan Dan Kebudayaan Nomor 23 Tahun 2016 Tentang Standar Penilaian Pendidikan,” Jakarta, 2016.

[18] Kemendikbud, "Peraturan Menteri Pendidikan dan Kebudayaan Nomor 24 Tahun 2016 Tentang Kompetensi Inti dan kompetensi dasar pelajaran pada Kurikulum 2013 pada pendidikan dasar dan pendidikan menengah," Jakarta, 2016.

[19] L. M. Marco-Bujosa, K. L. McNeill, M. González-Howard, and S. Loper, "An exploration of teacher learning from an educative reform-oriented science curriculum: Case studies of teacher curriculum use," J. Res. Sci. Teach., vol. 54, no. 2, pp. 141-168, 2017, doi: 10.1002/tea.21340.

[20] E. A. Davis, F. J. J. M. Janssen, and J. H. Van Driel, "Teachers and science curriculum materials: where we are and where we need to go," Stud. Sci. Educ., vol. 52, no. 2, pp. 127-160, 2016, doi: 10.1080/03057267.2016.1161701.

[21] Muslimin and Destriana, "Evaluation of curriculum implementation of 13 sports and health education teachers," Univers. J. Educ. Res., vol. 8, no. 1, pp. 27-35, 2020, doi: 10.13189/ujer.2020.080104. 